\title{
Strategic Alliance for a Technology-Fashion Product
}

\author{
Yun-Hee Kim* \\ Department of Marketing, McKendree University, IL, USA
}

Submission: October 17, 2017; Published: November 27, 2017

*Corresponding author: Yun-Hee Kim, Department of Marketing, McKendree University, IL, USA, Tel: 618-537-6939;

Email: ykim@mckendree.edu

\begin{abstract}
A strategic alliance has been used in various terms, including co-marketing, strategic partnership, interfirm cooperation, and cooperative strategies. A strategic alliance is a cooperative arrangement among partners who share skills and resources to yield high/superior productivities for each individual firm's profits. Using strategic alliance for luxury products may be an effective way of enhancing the value of products. The combination of two companies' strengths not only provides greater outputs, but also nurtures consumers' expectation toward the products. Because more and more industries will use this kind of alliances, academic researchers will need to pay attention to those consumers who prefer unique marketing strategies.
\end{abstract}

Keywords: Strategic alliance; Synergy; Fashion technology

\section{Introduction}

Since the 1990s, the majority of American domestic firms have entered an international market, and this flood of activity has let to heavy competition [1]. This competitive market environment has pushed these companies to be innovative and constantly upgrade their products in order to remain viable in the market. To respond at a high level to customers' needs, many companies have attempted to implement new retail strategies such as Mass Customization (MC). Introduced by Davis [2], the term "mass customization" indicates a system that uses information technology to allow individual customers to design products to meet their specific needs and preferences. This MC has been applied by different retailers, such as apparel (e.g., Levi's), greeting cards (e.g., Hall Mark), and eyewear (e.g., Paris Miki). The effective adaption of MC offers customers to experience both "aesthetic and functional fit" and uniqueness (boosting differentiation from other customers) among an infinite variety of products $[3,4]$. The innovative aspect of MC especially satisfy consumers' uniqueness-seeking need by providing scarce goods and services [4].

Although customization provides a major point of individualization or uniqueness, it has its limits in operational capabilities and demand [5,6]. Technology can support largescale customization; however, this customization is limited for a few attributes and a few products. Further, the consumer demand for customization is not substantial enough to provide profits to marketers [6]. In particular, consumers are not prepared to have everything customized [6] because they fear to be extremely dissimilar relative to others [7]. Not surprisingly, the popularity of MC has diminished among companies and academic researchers since the early 2000s. Under this circumstance, business firms need a powerful strategy to overcome the limitations of MC. A new strategy of marketing has been developed that has many of the advantages of MC but without its limitations. This strategy is called "a strategic alliance."

A strategic alliance has been used in various terms, including co-marketing, strategic partnership, interfirm cooperation, and cooperative strategies [8]. A strategic alliance is a cooperative arrangement among partners who share skills and resources to yield high/superior productivities for each individual firm's profits [8]. While MC is co-creation between suppliers and consumers, a strategic alliance is co-creation between two firms. The alliance between two companies, especially from different industries, enhances synergy, which is "the ability of the firm to exploit existing knowledge and resources to make a new product and is considered to be an aspect of firm strategy" [9]. Especially, the technology and fashion industries have engaged in synergy to add symbolic values to products or services via luxury brand images. Since LG Telecom (an electronic company), and Prada (a luxury apparel brand) collaborated and created a "Prada Phone," [10] many companies have introduced collaborated products to the luxury market such as "the world's first luxury Android Wear Smartwatch" by TAGHeuer collaborating with Google's Android 
operating system [11]. Such products created from strategic alliance between two businesses can provide unique benefits to consumers by offering both utilitarian (i.e., technology) and hedonic (i.e., fashion) attributes, leading to customer satisfaction.

\section{Conclusion}

The role of technology or fashion is not limited to either functional or aesthetic aspect. This creates the value of fashion to technology and allows this technology product to extend to the fashion industry. Using strategic alliance for luxury products may be an effective way of enhancing the value of products. The combination of two companies' strengths not only provides greater outputs, but also nurtures consumers' expectation toward the products [8]. Because the two well-known companies produce one product integrating each company's strengths, the quality of the product gains credibility. The collaboration provides an opportunity to technology and fashion marketers to adopt new elements from other industries. Accelerated use of alliance marketing has created a paradigm shift, and as a result, many companies selling different products have collaborated for competitive advantages $[8,12]$. Recently, the car industry has used this strategy alliance to accentuate the uniqueness of their products. Hyundai, the Korean automaker, and Prada, the Italian fashion brand, collaborated and created "Genesis Prada" [13]. Aesthetic features such as Prada's signature top quality leather and a new rear entertainment system distinguish this special edition luxury sedan. For the same reason, ErmenegildoZegna, the Italian luxury fashion house, and Maserati, the Italian luxury vehicle manufacturer, collaborated to create bespoke interiors for a concept car [14]. This kind of strategy tends to advance both companies' potential worldwide success because their cooperation provides more benefits than an individual firm can do alone. Because more and more industries will use this kind of alliances, academic researchers will need to pay attention to those consumers who prefer unique marketing strategies. Although many studies have focused on the B2B context dealing with fit between alliances' resources [15-18], few have investigated how consumers perceive and adopt these alliances. Thus, future research may want to examinehow strategic alliance creates new markets and affect consumers' decision-making.

\section{References}

1. Kotabe M, Swan KS (1995) The role of strategic alliances in hightechnology new product development. Strategic Management Journal 16(8): 621-636.

2. Davis FD (1989) Perceived usefulness, perceived ease of use, and end user acceptance of information technology. MIS Quarterly 13(3): 319340.

3. Frank N, Schreier M (2008) Product uniqueness as a driver of customer utility in mass customization. Marketing Letters 19(2): 93-107.

4. Lynn M, Harris J (1997) Individual differences in the pursuit of selfuniqueness through consumption. Journal of Applied Social Psychology 27(21): 1861-1883.

5. Gilmore JH, Pine BJ 2nd (1997) The four faces of mass customization. Harv Bus Rev 75(1): 91-101.

6. Zipkin P (2001) The limits of mass customization. MIT Sloan Management Review 42(3): 81-87.

7. Lynn M, Snyder CR (2002) Uniqueness seeking. In: Snyder CR \& Lopez SJ (Eds.), Handbook of positive psychology: Oxford University Press, London, pp. 395-410.

8. Carlson BD, Frankwick G, Cumiskey KJ (2011) A framework for understanding new product alliance success. Journal of Marketing Theory and Practice 19(1): 7-26.

9. Calantone RJ, Chan K, Cui AS (2006) Decomposing product innovativeness and its effects on new product success. The Journal of Product Innovation Management 23(5): 408-421.

10. Ramstad E, Fowler GA (2007) The cell phone wears Prada. Wall Street Journal 249(15): B5.

11. TAGHeuer.https://www.tagheuer.com/en-us/watches/tag-heuerconnected

12. Venkatesh R, Mahajan V, Muller E (2000) Dynamic co-marketing alliances: when and why do they succeed or fail? International Journal of Research in Marketing 17(1): 3-31.

13. https://www.hyundaiusa.com/search.aspx?q=genesis+prada

14. https://www.maserati.com/maserati/international/en/brand/ partners/ermenegildozegna

15. Albers S, Wohlgezogen F, Zajac EJ (2013) Strategic alliance structures: an organization design perspective. Journal of Management 39(7): 1-33.

16. Christoffersen J (2013) A review of antecedents of intentional strategic alliance performance: synthesized evidence and new directions for core constructs. International Journal of Management Reviews 15(1): 66-85

17. Ma C, Yang Z, Yao Z, Fisher G, Fang E (2012) The effect of strategic alliance resource accumulation and process characteristics on new product success: exploration of international high-tech strategic alliances in China. Industrial Marketing Management 41(3): 469-480.

18. Schulze A, Brojerdi G, Krogh G (2013) Those who know, Do. Those who understand, tech. disseminative capability and knowledge transfer in the automotive industry. J Prod Innov Manag 31(1): 79-97. 
Your next submission with Juniper Publishers will reach you the below assets

- Quality Editorial service

- Swift Peer Review

- Reprints availability

- E-prints Service

- Manuscript Podcast for convenient understanding

- Global attainment for your research

- Manuscript accessibility in different formats

( Pdf, E-pub, Full Text, Audio)

- Unceasing customer service

Track the below URL for one-step submission https://juniperpublishers.com/online-submission.php 